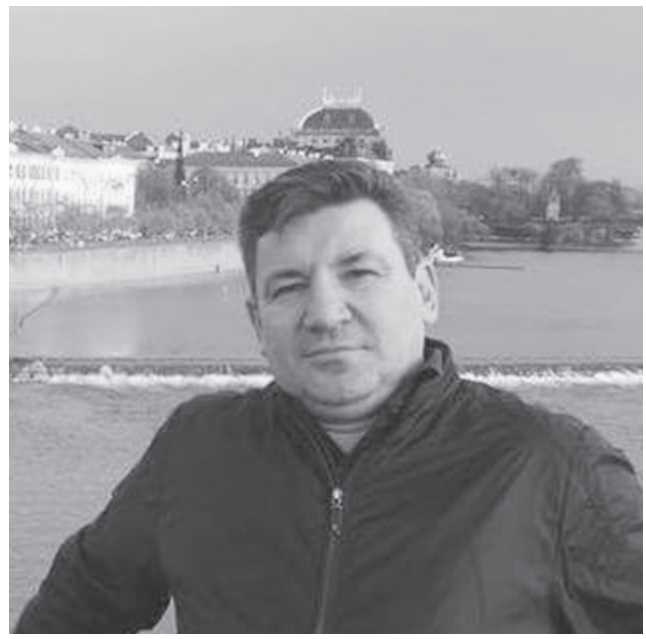

Филоненко Сергей Викторович, аспирант кафедры публичной службы и управления учебными и сощиальными учреждениями Луганского начионального университета имени Тараса Шевченко, 61002, г. Старобельск, тел.: (093)6699747, е-таil:ADegtyar@3g.ua

ORCID: 0000-0001-9256-2585

DOI: 10.32689/2414-0562-2018-15-5-256-266

\title{
DIRECTIONS OF IMPROVEMENT OF INSTITUTIONAL AND ECONOMIC MECHANISM OF INDUSTRIAL POLICY IN UKRAINE
}

Abstract. The article discusses the advantages and disadvantages of the current stage of economic development of the production sector of Ukraine. The question of the need for the development and availability of opportunities for the implementation of an active industrial policy is related to the following circumstances: in Ukraine, there are conditions for the manifestation of the activity of private capital, which owns funds and financial resources that are quite comparable to the resources of the state, and is capable of implementing economic reforms in the scientific and industrial sphere; private capital begins to realize and formulate its own interests and priorities, to show the ability to self-organization; in the current situation, the modernization of domestic industry is a necessary condition for ensuring high-quality economic growth, and its implementation is impossible without the development and implementation of targeted policies, combining to solve this national problem of the efforts of the state and private capital of considerable economic strength, which is not inferior in its potential to the public sector. 
It is found out that the clear structure of the state industrial policy of Ukraine at the moment is not defined. The institutional and economic mechanism of industrial policy in Ukraine is proposed, as well as its components are investigated.

The application of the proposed institutional and economic mechanism for the implementation of the state industrial policy will improve the efficiency of overcoming the above problems not only by clearly structuring the goals, objectives, tools and methods of industrial policy, the study of the effectiveness of its individual elements on the basis of the analysis of performance indicators, but also by increasing the interaction between subjects and objects of industrial policy with increasing influence of institutional components on the development of the industrial complex of the state as a whole.

Keywords: state, industrial policy, institutional and economic mechanism, sectoral approach, strategy of structural transformations in industry.

\section{НАПРЯМИ УДОСКОНАЛЕННЯ ІНСТИТУЦЙНО- ЕКОНОМІЧНОГО МЕХАНІЗМУ ЗДІЙСНЕННЯ ПРОМИСЛОВОЇ ПОЛІТИКИ В УКРАЇНІ}

Анотація. Розглянуто переваги та недоліки сучасного етапу економічного розвитку виробничої сфери України. Постановка питання про необхідність розробки і наявності можливостей здійснення активної промислової політики пов'язана з наступними обставинами: в Україні склалися умови для вияву активності приватного капіталу, що володіє коштами і фінансовими ресурсами, цілком порівнянними з ресурсами держави, і здатного на здійснення економічних перетворень у науково-промисловій сфері; приватний капітал починає усвідомлювати і формулювати свої власні інтереси і пріоритети, виявляти здатність до самоорганізації; у сформованій ситуації модернізація вітчизняної промисловості є необхідною умовою для забезпечення якісного економічного зростання, а їі проведення неможливе без розроблення та здійснення цілеспрямованої політики, об'єднання для вирішення цього загальнонаціонального завдання зусиль держави і приватного капіталу значної економічної сили, що не поступається за своїм потенціалом державному сектору.

3'ясовано, що чітка структура державної промислової політики України на даний момент не визначена. Запропоновано інституційно-економічний механізм здійснення промислової політики в Україні, а також досліджено його складові.

Застосування запропонованого інституціонально-економічного механізму реалізації державної промислової політики дасть можливість підвищити ефективність подолання зазначених проблем не тільки за рахунок чіткої структуризації цілей, завдань, інструментів і методів промислової політики, дослідження ефективності функціонування її окремих елементів на основі аналізу індикаторів результативності, але й шляхом збільшення взаємодії між суб'єктами та об'єктами промислової політики при посиленні впливу 
інституціональних складових на розвиток промислового комплексу держави загалом.

Ключові слова: держава, промислова політика, інституціонально-економічний механізм, галузевий підхід, стратегія структурних перетворень у промисловості.

\section{НАПРАВЛЕНИЯ СОВЕРШЕНСТВОВАНИЯ ИНСТИТУЦИОНАЛЬНО-ЭКОНОМИЧЕСКОГО МЕХАНИЗМА ОСУЩЕСТВЛЕНИЯ ПРОМЫШЛЕННОЙ ПОЛИТИКИ В УКРАИНЕ}

Аннотация. Рассмотрены преимущества и недостатки современного этапа экономического развития производственной сферы Украины. Постановка вопроса о необходимости разработки и наличии возможностей осуществления активной промышленной политики связана со следующими обстоятельствами: в Украине сложились условия для проявления активности частного капитала, которая владеет средствами и финансовыми ресурсами, вполне сопоставимыми с ресурсами государства, и способного на осуществление экономических преобразований в научно-промышленной сфере; частный капитал начинает осознавать и формулировать свои собственные интересы и приоритеты, проявлять способность к самоорганизации; в сложившейся ситуации модернизация отечественной промышленности является необходимым условием для обеспечения качественного экономического роста, а ее осуществление невозможно без разработки и целенаправленной политики, объединения для решения этой общенациональной задачи усилий государства и частного капитала значительной экономической силы, что не уступает по своему потенциалу государственному сектору.

В связи с тем, что четкая структура государственной промышленной политики Украины на данный момент не определена, предложен институционально-экономический механизм осуществления промышленной политики в Украине, а также исследованы его составляющие.

Применение предложенного институционально-экономического механизма реализации государственной промышленной политики, позволит повысить эффективность преодоления вышеупомянутых проблем не только за счет четкой структуризации целей, задач, инструментов и методов промышленной политики, исследования эффективности функционирования ее отдельных элементов на основе анализа индикаторов результативности, но и путем увеличения взаимодействия между субъектами и объектами промышленной политики при усилении влияния институциональных составляющих на развитие промышленного комплекса государства в целом.

Ключевые слова: государство, промышленная политика, институционально-экономический механизм, отраслевой подход, стратегия структурных преобразований в промышленности. 
Problem statement. At the present stage of economic development, the production sphere of Ukraine has a number of advantages: a rich raw material base and the availability of scientific and technical potential, and a number of significant shortcomings: the technological lag of Ukraine from the leading European countries, widespread wear and low level of equipment of fixed assets, the mismatch of the structure of industrial production parameters' characteristic of the economies of developed industrial countries. However, a clear structure of the state industrial policy of Ukraine at the moment is not defined, though, on the basis of theoretical and practical experience it is possible to build an institutional and economic mechanism of industrial

Analysis of recent research and publications. General methodological aspects of the formation and implementation of the state industrial policy are covered in the works of both foreign and domestic scientists. A significant contribution to the study of the state impact on industry was made by scientists such as A. M. Horskyi [5], L. V. Deineko [6], V. M. Yemelianov [7], T. L. Zheliuk [1], A. S. Zarudna [5], I. S. Kalinichenko [5], L. P. Klimenko [7], P. V. Krush [8], I. A. Maksymenko [8], L. V. Peltek [3], T. A. Stovba [9], N. V. Tarasova [7], K. I. Tkach [10], V. Ye. Khaustova [11], E. I. Sheludko [6] and others. The ideas and provisions set out in the works of these authors served as the basis for the further development and implementation of industrial policy. However, despite numerous studies, the formation of the institutional and economic mechanism for the implementation of industrial policy in Ukraine remains insufficiently covered.

Formulation of the aims of the article. The purpose of this article is to identify the main elements of industrial policy at the macro level and the formation of the design of the institutional and economic mechanism of its implementation, as well as the rationale for proposals to improve this mechanism.

Presentation of the main material of the study. The issue of the need for the development and availability of opportunities for the implementation of an active industrial policy is related to the following circumstances:

- in Ukraine, there are conditions for the manifestation of the activity of private capital, which owns funds and financial resources that are quite comparable to the resources of the state, and is capable of implementing economic reforms in the scientific and industrial sphere; private capital is beginning to realize and formulate its own interests and priorities, to show the ability to self-organization.

- in the current situation, the modernization of domestic industry is a necessary condition for ensuring highquality economic growth [8, p. 64], and its implementation is impossible without the development and implementation of targeted policies, combining the efforts of the state and private capital of considerable economic strength to solve this national problem, which is not inferior in its potential to the public sector;

- with the development of large domestic companies, their role in the modernization of the country will increase, because it is here that the most qualitative resources of national development 
are concentrated today: professional personnel, managerial competence, advanced technologies and financial resources.

The study of the development of the industrial sector of the economy of Ukraine showed that in general there are positive trends. Regarding the structure of the industrial production of Ukraine in terms of shipped goods of own production, the leading industries are the food industry, chemical industry, metallurgical production [11, p. 35].

Nevertheless, a number of socially important industries, such as light industry, furniture production are developing ineffectively and not innovatively, which causes disproportions in the development of the industrial complex of the state as a whole. It should be noted that the company is a key level for determining the competitiveness of the country as a whole. And the companies, along with industrial clusters, but not the region should be the main subjects of industrial policy.

Each group has a demand for its own version of industrial policy. It is obvious that the choice of strategy should be made taking into account the interests of the majority.

Universal measures to create an enabling institutional environment without reference to a specific group of enterprises are most applicable. At the same time, it is impossible to ignore some industry-specific features that are subject to special measures, such as "tax holidays", direct subsidies for the costs of development in the field of innovation and development of new products.

In order to implement the main priorities of industrial policy, namely, the growth of production of competitive products, creating a favorable investment and innovation climate, overcoming technological backwardness, support for competition in sectors and spheres of the national economy and the solution of other tasks of the state industrial policy, the state administration and their sectoral ministries and departments develop and implement a number of federal projects and targeted development programs for each sector separately, on the Basis of the strategy of sustainable development "Ukraine". - 2020" [4] in which the main areas which need support are highlighted. The priority industries, in accordance with the Strategy, include pharmacology, medical equipment, electricity, aerospace and other high-tech industries.

The lack of a targeted economic growth strategy that is adequate to the dominant trends in world development has led to the intensification and intensification of discussions on the future of the Ukrainian economy.

Today, it is quite obvious that if current levels of material and energy intensity of production, productivity and the existing structure of the economy are saved, its development is faced with resource constraints objective [3, p. 85]. The instability of world energy prices and the reduction of the developed raw material base in the metallurgical and chemical industries give rise to more doubts about the reliability of reliance on raw materials exports to ensure high sustainable economic growth and solve acute social problems.

Under these conditions, improving the efficiency and competitiveness of manufacturing industries and hightech industries is an alternative way of socio-economic development. Do- 
mestic industry is already facing or will face the following problems in the near future:

- a significant increase in the costs of manufacturing enterprises and the limitation of their investment potential due to the rapid growth of relative prices for products (services) of natural monopolies;

- reduction of competitiveness of domestic goods due to significant inflation;

- increased localization of investment resources outside of the manufacturing sector due to rapid growth of investment in fixed capital in exportoriented primary industries [5, p. 54].

In this context, for a deeper understanding of the economic essence of industrial policy, it is necessary to pay attention to the main institutions that create the conditions for its implementation and are defined in a general by D. North in his institutional theory as the "rules of the game" in society or the restrictive framework created by man, which organize the relationship between people [2, p. 38].

The role of the institutional component in the functioning of economic systems is undeniable, since the relationship between society and the economy is determined by a set of institutional constraints that determine the basic structure of the incentives of the economic system and monitor the observance of these rights, acting as the main determinants of the functioning of the economy [7, p. 42], as a dynamic system that is regulated by the state. Institutions are also the keys to understanding the relationship between business and management as part of an effective industrial policy.
At the moment, the set of methods and tools for the implementation of industrial policy is quite wide, however, there is no effective mechanism for the implementation of industrial policy. In this regard, on the basis of theoretical analysis and research of practical experience, the institutional and economic mechanism for the implementation of the state industrial policy is formulated, developed for application at the macro level, which can be designed at the meso-and municipal levels, if necessary, is reflected in table 1.

The implementation of the proposed institutional and economic mechanism for the implementation of the state industrial policy involves not only effective interaction between subjects and objects within the framework of the identified priorities, taking into account the features and patterns of development of the domestic economy, but also the goals and objectives, based on the formulated principles, through the use of appropriate institutional and economic tools and methods, act as fundamental factors in the functioning of industrial policy and have a direct impact on the effectiveness of its implementation.

In the context of the Association of Ukraine and the EU, improving national competitiveness, compliance with international standards and the expansion of the share of domestic companies as the main source of welfare of citizens of the country with the continuous growth of their living standards are the main determinants of industrial development.

At the same time, the increase in the relative prices of products (services) of natural monopolies leads to a decrease 
in GDP growth rates, deterioration of the financial condition of enterprises, especially in the manufacturing industry.

The initiated reforms in the sphere of natural monopolies have not yet gained the proper pace and remain only a potential factor of economic growth. So far, no such schemes have been found to ensure transparency of the cost struc- ture at all stages. Ultimately, the reform should lead to improved efficiency of natural monopolies and slowing growth in the value of their products (services) and not to continuous growth rates [6, p. 82]. However, while barriers to access to the electricity market remain, the wholesale energy market is not developing at a sufficient pace, natural monopolies retain significant non-core

\section{The main components of the institutional and economic mechanism of industrial}

policy

\begin{tabular}{|c|c|}
\hline Subjects & $\begin{array}{l}\text { The President of Ukraine, the Verkhovna Rada of Ukraine, the Cabinet of Min- } \\
\text { isters of Ukraine, including ministries and departments, management bodies } \\
\text { implementing Supervisory, control and other management functions }\end{array}$ \\
\hline Objects & $\begin{array}{l}\text { Enterprises under public ownership; industrial enterprises with equity partici- } \\
\text { pation of the state; private companies that are the subject of legislation }\end{array}$ \\
\hline Purpose & $\begin{array}{l}\text { Achievement of sustainable development of the industrial complex on the ba- } \\
\text { sis of interaction of participants in the process of development and implemen- } \\
\text { tation of industrial policy, the maximum use of the potential of modernization } \\
\text { of production }\end{array}$ \\
\hline Basic tasks & $\begin{array}{l}\text { - ensuring the competitiveness of production; } \\
\text { - stimulating domestic demand for industrial products; } \\
\text { - development of public-private partnership in industry; } \\
\text { - to promote the integration of and transnational character of companies; } \\
\text { - support for the development of science-intensive industry; } \\
\text { - priority for innovation-oriented companies }\end{array}$ \\
\hline $\begin{array}{l}\text { Basic } \\
\text { principles }\end{array}$ & $\begin{array}{l}\text { consistency; reflexivity; attraction of private investments; effective dialogue } \\
\text { between the government and business; diversification; inter-industry capital } \\
\text { overflow taking into account current and strategic priorities of the industry }\end{array}$ \\
\hline \multicolumn{2}{|r|}{ Institutional components } \\
\hline Methods & $\begin{array}{l}\text { Legislative regulation; public-private partnership; public procurement; lobby- } \\
\text { ing }\end{array}$ \\
\hline Tools & $\begin{array}{l}\text { Laws and regulations; state order; reforming of natural monopolies and state } \\
\text { corporations; contracts, agreements; tools of civilized bankruptcy; public- } \\
\text { state dialogue business-power }\end{array}$ \\
\hline \multicolumn{2}{|r|}{ Economic components } \\
\hline Methods & $\begin{array}{l}\text { Economic (financial, tax, customs, tariff, banking); management of state } \\
\text { property in industry; programming; design }\end{array}$ \\
\hline Tools & $\begin{array}{l}\text { - implementation of economic policy (customs, credit, tax, investment, } \\
\text { innovation and technology); } \\
\text { - preferential crediting of export of goods, technologies-leasing of expensive } \\
\text { machinery and equipment; } \\
\text { - standardization and certification; } \\
\text { - development of production infrastructure; } \\
\text { - implementation of state target programs and projects }\end{array}$ \\
\hline
\end{tabular}


assets, investments, there is no proper transparency in conducting large purchases, the formation of competitive markets and the removal of barriers to entry into the relevant markets of other companies is very slow.

Investment problems of natural monopolies are solved by including the corresponding costs in the cost price and thus are transferred to consumers. It puts natural monopolies and other industries in unequal conditions in comparison with.

Regarding export credit and organization of leasing of expensive and hightech products, it is carried out at the state level under the scheme:

- lending directly or indirectly to the supply of science-intensive products for export, especially with a long production cycle;

- leasing as the main form of purchase of expensive equipment, especially in the aviation industry;

- lending to the population for the purchase of expensive products at an acceptable Bank interest, to ensure the further development of mortgages [8, p. 92].

As an objective specificity of the development of the domestic economy, it should be noted that there are intensive processes of industrial integration. The attitude to these processes is different, but they are largely due to the lack of effective institutions (banking system, stock market, contracts, etc.). In fact, the main investment resources are concentrated in a limited number of export-oriented integrated industrial groups in the form of holdings and strategic alliances. Diversification of assets of such groups in the direction of enterprises of manufacturing industries is the most real operating mechanism of capital transfer from the export-oriented raw materials sector of the domestic economy to the manufacturing sector [10, p. 37].

Despite the existence of a legislative framework, the creation of favorable conditions for the development of the real sector of the economy as a whole and priority support for certain sectors, there are some negative aspects in the state industrial policy, in particular:

1. Currently, most of the state target programs are actually the plan of the state order.

2. Many industries are supported only within the framework of systemwide policy, and priority support is not covered, but still need it (in particular, textiles, clothing and food industries).

3. There is no or insignificant consideration of the territorial aspects of production (in this connection, the issue of industrial policy activation at the meso- and municipal levels is more acute).

In this regard, the effectiveness of the implementation of modern industrial policy in Ukraine is not large enough, does not meet the modern laws of globalization and prevents the strengthening of Ukraine's competitive position in the world economic space, which in turn requires:

- development and adoption of a number of restructuring programs, determine measures for the development or reduction of a number of industries (both sectoral and territorial);

- strengthening measures to lobby the interests of domestic producers in the world market [9, p. 34];

- measures for temporary protection of the relevant markets for finished 
products, in particular, to reduce import duties on imported equipment that has no domestic analogues;

- reduction of customs restrictions that make it difficult for large foreign investors to enter the domestic market.

The application of the proposed institutional and economic mechanism for the implementation of the state industrial policy will improve the efficiency of overcoming the above problems not only by clearly structuring the goals, objectives, tools and methods of industrial policy, the study of the effectiveness of its individual elements on the basis of the analysis of performance indicators, but also by increasing the interaction between subjects and objects of industrial policy with increasing influence of institutional components on the development of the industrial complex of the state as a whole.

Conclusions from this study and prospects for further exploration.

As a result of the study, it is possible to draw the following conclusions::

- a clear structure of the state industrial policy of Ukraine at the moment is not defined, however, on the basis of theoretical and practical experience, it is possible to build an institutional and economic mechanism of industrial policy from the macro level, includes: the purpose and objectives, basic principles and methods, tools, performance assessment, as well as the allocation of a separate block of institutional components of industrial policy;

- the study of the practice of state industrial policy in Ukraine in recent years allows us to judge the diversity and a wide range of activities in the field of regulation and support of industrial development. Among priority di- rections of development of the industry we should highlight the pharmacology, the production of honey, technology, aerospace, information technology, innovation and nanotechnology;

- nevertheless, there are sectoral and territorial disparities in the development of industry, which require a clear allocation and structuring of competencies of different levels of government and the activation of diversified activities carried out at the meso- and municipal levels in the framework of industrial policy in accordance with the basic conditions of development of individual territorial entities.

\section{REFERENCES}

1. Zhelyuk T. L. (2010), Upravlinnya dovgostrokovym rozvytkom nacional'noyi ekonomiky: metodologichni ta prykladni aspekty [Management of long-term development of national economy: methodological and applied aspects], TNEU publ, Ternopil, Ukraine.

2. Nort D. K. (1997), Institutyi, institutsionalnyie izmeneniya $\mathrm{i}$ funktsionirovanie ekonomiki [Institutions, institutional change and economic performance], Fond ekonomicheskoy knigi "Nachala" publ, Moscow, Russia.

3. Pel'tek L. V. (2010), Rozvytok rehional'noyi promyslovoyi polityky derzhavy: teoriya, metodolohiya, mekhanizmy [The development of regional industrial policy: theory, methodology, tools], ChDU Publ., Mykolayiv, Ukraine.

4. President of Ukraine (2015), Decree of the President of Ukraine "On the strategy of sustainable development "Ukraine-2020" available at: http:// zakon.rada.gov.ua/laws/show/5/2015 (Accessed 14 September 2018). 
5. Tarasova N. V., Kalinichenko I. S., Hors'kyy A. M., Zarudna O. S. (2005), Promyslovyy kompleks Ukrayiny: ekonomichni transformatsiyi ta priorytety rozvytku [The industrial complex of Ukraine: economic transformation and development priorities], Nauk. Svit Publ., Kyiv, Ukraine.

6. Deyneko L. V., Yakubors'kyy M. M., Shelud'ko E. I. (2014), Promyslova polityka postkryzovoyi ekonomiky, [Industrial policy post-crisis economy], In-t ekonom. ta prohnoz. NAN Ukrayiny Publ., Kyiv, Ukraine.

7. Tarasova N. V., Klymenko L. P., Yemel'yanov V.M. (2011), Promyslovist' Ukrayiny: tendenciyi, problemy, perspektyvy, [Industry of Ukraine: trends, problems, prospects.], In-t ekonom. ta prohnoz. NAN Ukrayiny Publ., Kyiv, Ukraine.

8. Krush P. V., Maksymenko I. A. (2008), Regulyuvannya ekonomiky: teorety'chni ta prykladni aspekty [Economic regulation: theoretical and applied aspects], NTUU "KPI" Publ., Kyiv, Ukraine.

9. Stovba T. A. (2010), Systemne vidrodzhennya pidpryemstv legkoyi promyslovosti na innovacijnyx zasadax [Systemic revival of light industry enterprises on the basis of innovation], Ajlant publ., Kherson, Ukraine.

10. Tkach K. I. (2008), Teoretychni zasady rehional'noyi promyslovoyi polityky [Theoretical zasadi regionalno promislovoe polity], Astroprynt Publ., Odesa, Ukraine.

11. Khaustova V. Ye. (2015), Promyslova polityka v Ukrayini: formuvannya ta prohnozuvannya, [Industrial policy in Ukraine, formation and forecasting], INZhEK Publ., Kharkiv, Ukraine.

\section{СПИСОК ВИКОРИСТАНИХ ДЖЕРЕЛ}

1. Желюк Т. Л. Управління довгостроковим розвитком національної економіки: методологічні та прикладні аспекти : монографія / Т. Л. Желюк. - Т. : ТНЕУ, 2010. $511 \mathrm{c}$.

2. Норт Д. К. Институты, институциональные изменения и функционирование экономики / Д. К. Норт. - М. : Фонд экономической книги “Начала”, 1997. - 180 с.

3. Пельтек Л. В. Розвиток регіональної промислової політики держави: теорія, методологія, механізми : монографія / Л. В. Пельтек ; НАН України, Рада по вивч. продукт. сил України, Чорномор. держ. ун-т ім. П. Могили. - Миколаїв : Вид-во ЧДУ, 2010. - 265 с.

4. Про Стратегію сталого розвитку "Україна-2020" [Електронний ресурс] : Указ Президента України від 12. 01. 2015 p. № 5/2015. - Режим доступу : http://zakon.rada.gov.ua/ laws/show/5/2015

5. Промисловий комплекс України: економічні трансформації та пріоритети розвитку : монографія / [Н. В. Тарасова, I. С. Калініченко, А. М. Горський, О. С. Зарудна та ін.]. -К. : Наук. світ, 2005. - 182 с.

6. Промислова політика посткризової економіки : монографія / [Л. В. Дейнеко, М. М. Якубовський, Е. І. Шелудько та ін.]; за ред. Л. В. Дейнеко, М. М. Якубовського ; НАН України, ДУ “Ін-т екон. та прогноз. НАН України”. - К. : Ін-т екон. та прогноз. НАН України, 2014. - 315 с.

7. Промисловість України: тенденції, проблеми, перспективи: монографія / [Н. В. Тарасова, Л. П. Клименко, В. М. Смельянов та ін.]. - Миколаїв: Вид-во ЧДУ ім. Петра Могили, 2011. - 320 c.

8. Регулювання економіки: теоретичні та прикладні аспекти : монографія / П. В. Круш, I. А. Максименко ; за заг. ред. П. В. Круш. - К. : НТУУ “КПІ”, 2008. - 424 c. 
9. Системне відродження підприємств легкої промисловості на інноваційних засадах : монографія / Т. А. Стовба. - Херсон : Айлант, 2010. - 295 c.

10. Ткач К. I. Теоретичні засади регіональної промислової політики : монографія / К. І. Ткач ; НАН України,
Ін-т пробл. ринку та екон.-екол. дослідж. - О. : Астропринт, 2008. $279 \mathrm{c}$.

11. Хаустова В. Є. Промислова політика в Україні: формування та прогнозування : монографія / В. С. Хаустова. - Х. : ІНЖЕК, 2015. $380 \mathrm{c}$. 